\title{
O relato de um paradoxo: a verdade da ficção e a utilidade da história em um discurso de José da Cunha Brochado na Academia Real da História Portuguesa (1730)
}

Report on a paradox: the truth of fiction and the usefulness of history in a discourse by José da Cunha Brochado at the Academia Real da História Portuguesa (1730)

\section{Pedro Telles da Silveira}

doca.silveira@gmail.com

Mestre

Universidade Federal de Ouro Preto

Rua Novo Hamburgo, 238 - Passo d'Areia

90520-160 - Porto Alegre - RS

Brasil

Palavras-chave

Historiografia moderna; Ficção; Ceticismo.

Keywords

Early Modern Historiography; Fiction; Skepticism. 
As long as there's one person to believe it, there's no story that can't be true.

Paul Auster

E se se dissesse que na história não é possível alcançar a verdade? E se se estendesse o argumento ao ponto de afirmar que essa mesma verdade é desnecessária à eficácia do discurso histórico? E caso se concluísse, então, que a historiografia goza do mesmo estatuto perante a verdade daquele da ficção, da fábula e da parábola? Essas e outras afirmações, que no panorama da escrita histórica das últimas décadas nos acostumamos a associar aos autores ligados ao linguistic turn, foram, na verdade, enunciadas em inícios do século XVIII. A ocasião? Um relato do andamento das pesquisas dos membros da Academia Real da História Portuguesa prestado em Lisboa, capital do Império lusitano.

O objetivo do presente texto é apresentar a comunicação lida por José da Cunha Brochado a seus colegas da Academia Real da História na conferência do dia 22 de setembro de 1730, destacando seus argumentos, sua importância no conjunto da reflexão elaborada pelos acadêmicos e alguns dos debates com os quais aquela comunicação se relaciona. Trata-se de um discurso acerca da impossibilidade de se alcançar a verdade na escrita da história - e de como, na opinião do autor, seria melhor à historiografia, caso deseje manter seus objetivos de instrução, abandonar a pretensão a um conhecimento factual e optar por uma verdade moral, daí o "paradoxo" assinalado pelo autor: a história é mais verdadeira quando não pretende contar a verdade. Como no debate contemporâneo, o questionamento dos limites entre a história e a ficção levanta o problema do ceticismo, isto é, da própria possibilidade de um conhecimento histórico capaz de responder aos anseios humanos.

Esta apresentação está dividida em três partes. Na primeira, indicarei algumas informações a respeito da vida do autor que ajudam a compreender sua importância, assim como seu papel na agremiação lisboeta. Num segundo momento, procurarei delinear alguns debates que ocorrem na Academia Real, em especial conforme ela passa da preparação para a edição de suas obras. Tentarei, portanto, contextualizar o discurso de Brochado no interior da própria academia para a qual foi lido. Por fim, buscarei detalhar seus argumentos e relacioná-los a alguns dos debates de sua época, em especial àqueles que dizem respeito às variantes do ceticismo histórico em um período marcado por grandes modificações na escrita histórica. O paradoxo trazido à tona por Brochado, portanto, não perdeu sua atualidade desde o momento em que ele surpreendeu seus colegas com seu persuasivo discurso: porque é tão difícil escrever uma história verdadeira? E porque é tão difícil aprender com a história?

\section{Em torno ao autor}

José da Cunha Brochado nasceu em Cascais, próximo a Lisboa, no dia 2 de abril de 1651. Seu pai, Antônio da Cunha da Fonseca, era administrador do Castelo de São Jorge. Como muitos de seus contemporâneos, Brochado recebeu educação jesuítica, todavia rejeitou o caminho paterno trocando as 
armas pelas letras, formando-se em Cânones na Universidade de Coimbra. Em Lisboa, ingressa na magistratura, onde com a exceção de um pequeno incidente ele progride rapidamente na carreira, angariando um cargo no Desembargo do Paço. A trajetória de Brochado repete o percurso típico dos magistrados portugueses e dos funcionários da administração lusitana; seria apenas quando de seu ingresso na diplomacia que ele alcançaria destaque.

Em 1695, Brochado recebe a incumbência de acompanhar D. Luís Álvares de Castro em embaixada a Paris. Este último, nobre de linhagem antiga, Conde de Monsanto e $2^{\circ}$ Marquês de Cascais, permanece na corte francesa até 1699, retornando a Lisboa. Com sua saída, Brochado assume as funções de enviado especial junto à corte do Rei Sol, onde permaneceria até 1704. Quando em Paris, o autor começa a escrever suas Memórias, pequenos apontamentos acerca de sua trajetória, sua convivência na França e os problemas portugueses. Embora publicadas postumamente, suas Memórias circulam em manuscrito e Ihe granjeiam, já em vida, a fama de pensador.

De volta a Portugal, ele assume posto no Conselho da Fazenda em 1706 e, dois anos mais tarde, passa a fazer parte do Conselho da Rainha. A atividade como conselheiro, cada vez mais próximo aos círculos dirigentes portugueses, é interrompida em 1710, quando é enviado a Londres em missão diplomática. Brochado permanece na capital inglesa por cinco anos, retornando a Portugal apenas em 1715.

Contando com mais de setenta anos de idade, ele é apontado, em 1721, para ingressar na recém-criada Academia Real da História Portuguesa, onde Ihe é indicada a tarefa de compilar os tratados diplomáticos celebrados por Portugal e escrever-lhes introduções históricas nas quais contextualizaria e problematizaria os mesmos. Brochado tem dificuldade - como veremos - em conseguir completar suas obrigações acadêmicas, ainda mais que em meados da década é designado para presidir as negociações para o casamento dos infantes de Portugal e Castela. Ele é bem-sucedido em sua missão, retomando as atividades na Academia Real em 1729. Na agremiação, o autor se dedica às tarefas de diretor e censor, além de tentar dar prosseguimento à compilação dos tratados portugueses. Esta tarefa é interrompida no dia 27 de setembro de 1733, quando falece após uma longa e ocupada vida.

Na historiografia portuguesa, a memória de José da Cunha Brochado está ligada à figura dos estrangeirados, indivíduos que saíram de Portugal e forneceram, por meio de seus escritos, uma espécie de espelho para os problemas enfrentados pela nação lusa. Sendo assim, Brochado é considerado um dos precursores do Esclarecimento em solo português (BROCHADO 1909; 1944; CUNHA 2001). ${ }^{1}$ Não se trata de desmentir ou confirmar interpretações como estas, mas sim de compreender o que a trajetória do autor pode revelar acerca de sua atuação na Academia Real e do caráter desta mesma agremiação.

\footnotetext{
${ }^{1}$ Para além destas referências para a vida e a recepção da obra de José da Cunha Brochado, há também o livro de Maria Rosalino Pinto da Ponte Delgado, José da Cunha Brochado (1651-1733): o homem e a sua época, ao qual infelizmente não tive acesso.
} 
Em seu estudo sobre a academia lisboeta, Isabel Ferreira da Mota distingue seus integrantes entre algumas classes, das quais se destacam os historiadores do cursus honorum e os grandes amadores (MOTA 2005, p. 140141). Os primeiros seriam aqueles que têm a escrita como ocupação principal e que buscam, ao servir na Academia Real da História, aproximar-se das grandes personagens da nobreza lusitana, na tentativa de alcançarem um título nobiliárquico. Os grandes amadores, por sua vez, representariam os membros da mais alta camada aristocrática lusa, assim como os membros superiores do clero e do funcionalismo português. Segundo Isabel Mota, estes amadores "teriam escolhido a História como disciplina privilegiada porque a honra suprema era a integração e a direção da Academia Régia", o que não Ihes impedia de assumir "posições intelectuais mais avançadas e perigosas. Eles tinham muito menos a temer que os outros" (MOTA 2004, p. 152). Ao contrário de seus colegas do cursus honorum, os amadores frequentemente ocupavam os cargos de direção da agremiação lusitana; em compensação, passavam por dificuldades muito maiores no que toca a completarem suas tarefas, de modo que sua produção escrita, em comparação, é bastante reduzida. Esta dicotomia entre amadores e "profissionais" é representativa do estatuto ambíguo da Academia Real, que premiava ao mesmo tempo o mérito e o sangue - e pelo caráter do desafio lançado por José da Cunha Brochado a seus companheiros, pela escassez de sua produção acadêmica e pela gama de postos imperiais assumidos em vida, torna-se mais fácil compreender sua atuação se o considerarmos como um dos membros deste simultaneamente 276 avançado e arcaico grupo de grandes amadores.

\section{A Academia Real dez anos após sua fundação}

A Academia Real da História Portuguesa celebrou sua primeira conferência no dia 8 de dezembro de 1720. Antes disso, o clérigo Manuel Caetano de Sousa, ao retornar de uma viagem pela Itália, propusera ao monarca D. João $V$ a reunião de eminentes letrados do Reino tendo em vista a composição de uma grande história eclesiástica de Portugal, a Lusitania Sacra (CDMARHP, ${ }^{2}$ "Proposição da Academia da História Eclesiástica de Portugal", 1721, p. 2). 0 monarca não apenas abraça a ideia como sugere a expansão para toda uma academia, composta por cinqüenta membros, dedicada ao estudo da história portuguesa e à composição, ao cabo, tanto de uma história eclesiástica quanto de uma história secular em língua latina. Os cinquenta acadêmicos seriam governados por um secretário perpétuo (o próprio Manuel Caetano de Sousa) e regidos por uma junta de quatro censores; as reuniões teriam um diretor, seriam realizadas quinzenalmente, aos domingos, e em cada uma delas quatro acadêmicos prestariam contas do andamento de seus estudos.

Com incomparável vigor, a agremiação lisboeta conseguiu manter a regularidade de suas reuniões por mais de uma década, conforme atestam os dezesseis volumes

\footnotetext{
${ }^{2}$ As referências às Coleções de Documentos, Memórias e Estatutos da Academia Real da História Portuguesa são indicadas, por motivos de espaço, sob a abreviação CDMARHP, acompanhada do título do documento ou, quando se tratar de conferência acadêmica, da data de sua realização, seguido do ano e do número de página, quando o houver.
} 
anuais de suas coleções de documentos e memórias. Perto de completar seu décimo ano de vida, entretanto, a Academia encontrava-se simultaneamente na posição de editar os primeiros resultados de suas investigações e de encontrar-se frente a frente com dúvidas e incertezas que terminariam, por fim, por minar suas pretensões. É nessa situação que encontramos o discurso de José da Cunha Brochado.

Embora a composição final em latim das duas histórias, a eclesiástica e a secular, fosse uma tarefa individual, ambas as obras seriam o resultado do labor coletivo de todos os acadêmicos. Para isso, distribuiu-se entre os agremiados um conjunto de temas que eles deveriam explorar em suas memórias históricas. ${ }^{3}$ As memórias eram obras nas quais os pontos duvidosos, as opiniões divergentes e os fatos incertos seriam elencados e debatidos, tendo em vista o preenchimento das lacunas da historiografia portuguesa. As memórias funcionam como uma espécie de escrita propedêutica à composição final de uma história, sendo desenvolvidas através do trabalho de pesquisa e investigação erudita. Como afirma Fernão Telles da Silva na conferência de 28 de agosto de 1721,

[...] a composição de memórias permite disputas de origens de nomes, questões, e provas de fatos duvidosos, dissertações, e discursos, que não se admitem na narração histórica de vidas dos Reis, Príncipes, Prelados, e Varões insignes (CDMARHP 28/08/1721, p. XI-XII).

A existência de um gênero como o das memórias aponta para a cisão entre pesquisa e narrativa que é representativa da historiografia da Idade Moderna, desde a diferenciação entre o antiquário e o historiador, passando pelo jurisconsulto, e chegando até o filósofo, na outro extremo desta distinção, em finais do século XVIII, frente ao historiador erudito. Os pontos de contato entre os dois gêneros, entretanto, indicam a existência de uma tensão - e não necessariamente uma rejeição - entre uma e outra forma historiográfica. Mais importante ainda, esta tensão revela que a historiografia era praticada, no período, sob formas que não cabem adequadamente na designação historiador. As tarefas ligadas à historiografia poderiam ser, por exemplo, as de compor uma narrativa histórica, produzir um resumo de uma obra maior, pesquisar em arquivo, produzir dissertações ou trabalhos monográficos, julgar outras obras, entre outras. Esta essencial incongruência entre a atuação disciplinar atual da historiografia e sua contraparte no começo da modernidade demonstra que essas diferentes funções eram combinadas de autor a autor e de momento a momento. Não por acaso a composição das memórias trazia tantos problemas à identidade da empresa historiográfica - questão candente que José da Cunha Brochado tentará a seu modo responder.

Era ponto pacífico que a escrita de memórias era muito distinta da composição de histórias. Como afirmou o acadêmico Manuel Pereira da Silva Leal, "Todos os

\footnotetext{
${ }^{3}$ As memórias históricas compartilham com o gênero das memórias o caráter propedêutico à história, todavia enquanto estas se fazem pela experiência pessoal do narrador, aquelas se resolvem por recurso à erudição e tratam de matérias que escapam ao alcance cronológico do narrador. As memórias históricas encontram seu precursor, ao menos para os membros da Academia Real, no erudito francês Sebastien Le Nain de Tillemont (1637-1698). José da Cunha Brochado foi autor de memórias no segundo sentido.
} 
preceitos, que os antigos, e modernos, com trabalho, e erudição juntaram, e procuraram reduzir a método, se devem observar inviolavelmente nas Memórias",

acrescendo a seu Autor, além do inexplicável trabalho de juntá-las, a obrigação de examinar os fatos controversos, ponderar, e referir os fundamentos das opiniões, que achou, e declarar o juízo, que fez sobre eles; ao mesmo tempo que o Historiador refere, sem ser obrigado a dar razão do seu dito: só da ligadura do estilo seguido sem interrupção, está dispensado (SILVA LEAL 1729, p. VII-VIII).

Apesar da clareza da distinção elaborada pelo autor, restava como problema o próprio papel do historiador ou memorista no momento de sua escrita: deveria ele pesar os argumentos dos diferentes autores e oferecer uma solução própria ou apenas elencar as respostas dadas anteriormente, deixando ao arbítrio do leitor - que, no caso, seria um historiador visando a composição de uma história - a escolha daquela que lhe parecesse a mais correta? A questão pareceria bizantina caso não tocasse justamente no ponto no qual, nas memórias, cruzavam-se a pesquisa e a escrita históricas. A seguinte passagem, escrita pelo Frei Lucas de Santa Catarina, revela a dimensão do problema:

Quanto à verdade, escrevo o que acho nas Histórias, especialmente nas nossas, ainda que tão disperso, e tão recopilado, que ainda olhando (como último arrimo) para aqueles antigos Escritores, antes tenho que lhe culpar os descuidos, que agradecer-lhe de documentos (SANTA CATARINA 1734, p. VIII, grifos meus).

Ou seja, o procedimento do frade lusitano consiste mais na cópia de diferentes autores do que na descoberta de documentos em arquivos; do mesmo modo, sua escrita se ordena mais pela tentativa de elencar opiniões do que efetivamente debatê-las e debelar falsas interpretações. O trabalho do memorista aproxima-se, em sua opinião, daquele do compilador. Surge outro paradoxo decorrente da situação específica da historiografia na Idade Moderna: se o memorista era um compilador, afastava-se da imagem do historiador, a qual estava ligada à composição de uma narrativa nova; porém conforme ele não oferecesse julgamentos, aproximava-se novamente deste historiador, preocupado apenas com a "ligadura" do estilo.

Esta dicotomia de fundo está presente no parecer dado por José da Cunha Brochado acerca da alcunha de cruel ou justiçoso a ser aplicada ao rei D. Pedro I pelo colega acadêmico Frei Bernardo de Castellobranco. Segundo o diplomata português, "me parece, que este caráter, ou imagem, [...] devem constituí-lo, e formá-lo as mesmas ações do Príncipe, e não a reflexão do Escritor", pois

Não é necessário por Lei precisa da História, que o Historiador se antecipe com reflexões, deve contentar-se com escrever coisas, como elas passaram, sem se intrometer a julgar delas; deixe ao seu Leitor o juízo livre sem o prevenir com invectivas, ou com apologias a tomar um, ou outro partido. Pouco, ou nada se deve achar na história, que venha do Autor (CDMARHP, "Parecer do Acadêmico José da Cunha Brochado", 1722, p. VII-VIII). 
Brochado deixa transparecer a partir de seu parecer que ele compreende a historiografia como uma narração o mais límpida, clara e contínua possível, de preferência sem interrupções acrescentadas pela presença do historiador em seu discurso. Percebe-se desde já que ele compartilha uma concepção tradicional da história, uma associada à narração e à instrução. O desafio colocado pelas memórias e pela erudição, entretanto, exige cada vez mais que o escritor se torne presente em seu discurso como árbitro entre opiniões divergentes. Surge, então, mais um questionamento: se o historiador não deve fazer juízos, como lidar com autores e textos que omitem, mentem ou, mais simplesmente, apenas tomam partido contrário à posição a ser defendida pelos integrantes da Academia Real? De que maneira é possível saber se se pode confiar nos autores?

Este problema acaba por assolar o trabalho de José da Cunha Brochado em sua integridade. Em sua primeira conta de estudos, datada de 22 de outubro de 1722, ele justifica o atraso no início de seu trabalho pela "igual dificuldade em descobrir os originais, e cópias autênticas, de que ela se deve compor, que em descrever, e conciliar depois a sua decência, e a sua importância" (CDMARHP 22/10/1722, p. I); o acadêmico reconhece, contudo, que mesmo os tratados originais não são de toda valia:

Destes tratados, e convenções públicas não há ordinariamente mais que umas noções gerais, e diminutas. [...] Alguns dos que se empregaram nelas, e que aprenderam utilmente esta ciência na sua mesma prática, $[\ldots]$ escreveram miudamente toda a história do Congresso, em que assistiram, mas com tanta dissimulação, e com tanto artifício, que mais parece que nos ostentam a honra das suas negociações, que nos comunicam o fruto das suas experiências (CDMARHP 22/10/1722, p. II).

Nesta passagem, onde se conjugam a utilidade do trabalho historiográfico com a dificuldade de acessar a verdade histórica através das fontes, o acadêmico dá vazão a problema que ganharia amplo destaque em seu posterior discurso. No ano seguinte, em 13 de maio de 1723, Brochado repete a conta de seus estudos, afirmando que "As Leis severas, que deve observar um fiel Historiador, ou Comentador, não compreendem a obra, de que estou encarregado" (CDMARHP $13 / 05 / 1723$, p. 101). Em agosto do mesmo ano, em reunião à qual não pode comparecer, leu-se seu depoimento, no qual argumentava que

A conta mais específica, e mais da minha obrigação seria ler agora alguns tratados antigos, cuja leitura nem é agradável pela matéria, nem pelo estilo; e menos seria útil, sem as disposições instrutivas para a sua inteligência. É de toda a história a parte menos atraente, serve mais para a instrução, e uso do ministério, que para aparato, e estudo das belas letras (CDMARHP 05/08/1723, p. 242).

Ao longo destas citações, percebe-se que muitas das dificuldades encontradas pelo autor advêm de sua tentativa de manter a história unificada enquanto uma narrativa de instrução moral pública, parte do ordenamento retórico das Belas Letras. A erudição, entretanto, colocava exigências cada vez 
maiores para a determinação da verdade do discurso histórico; como afirma o Marquês de Valença na conferência de 4 de janeiro de 1731:

\begin{abstract}
Se a principal obrigação do Historiador é referir os sucessos com a verdade mais pura, é a principal obrigação do Historiador resolver os pontos duvidosos da História, porque onde há dúvidas, e opiniões, não há certeza da verdade: [...] como pode o Sábio, ou o Historiador, que são sinônimos, deixar de opinar, senão resolver? (CDMARHP 04/01/1731, p. 2-3).
\end{abstract}

Por outro lado, a erudição não consegue transpor o limite que separa a investigação da narrativa histórica, preservando a concepção da própria separação entre estes dois momentos da prática historiográfica. Quanto a Brochado, ele simplesmente não parece talhado para a prática erudita e para o novo gênero das memórias históricas de que é encarregado - curiosamente, seria sua própria dificuldade em lidar com estas novas exigências que o levariam a adotar uma posição tão heterodoxa a respeito do caráter do discurso histórico no que toca à sua pretensão de verdade.

Chegado o momento de maturar os primeiros frutos da seara acadêmica, o otimismo das primeiras reuniões começa a ser substituído por dúvidas e escolhas cada vez mais pessoais. Em 1729, José do Couto Pestana assevera que

Nem tinha por maior cortesia crer, o que um Autor diz sem transcrever documentos, com o que prove, do que dar crédito aos documentos, que o outro transcreve, $[\ldots]$ e que contudo talvez era preciso refutar alguma opinião, e talvez todas, abrindo novo caminho para descobrir a verdade, não menos escondida no silêncio dos séculos, que nas vozes da sutileza, que inculca as aparências como realidades (CDMARHP 05/05/1729, p. 3).

Ou seja, a transcrição de documentos é elemento necessário para a crença em determinado autor, porém não é suficiente. Esse "esvaziamento" do documento Ihe faz ceder espaço frente à cada vez mais presente argumentação autoral, porém mesmo esta não é parâmetro suficiente para alcançar a certeza do conhecimento histórico:

Se eu escrever sem outros documentos, que os escritos, que se acham impressos, toda a prova, com que poderei qualificar a opinião, que seguir, a respeito dos sucessos, sobre os quais dissentem os Historiadores, será o melhor conceito, que eu forme do Escritor, ou Escritores, que eu aprovar; e deve consistir necessariamente na consideração do tempo, em que escreveram, dos empregos, que tiveram, da imparcialidade, que se percebe na forma, com que se referem, e nas mais razões, porque se estabelece a boa opinião dos Historiadores. Porém isto não será bastante, para que os fatos, que se acham duvidosos pela contrariedade dos referimentos, deixem de ficar da mesma sorte duvidosos, consistindo toda a prova da opinião que eu aprovar, na debilidade do meu discurso, e penetração, que parecerá grosseira, aos que se não acomodarem ao meu sentimento (CDMARHP 04/04/1731, p. 10-11, grifos meus). 
Também revelam o surgimento de problemas, na verdade, insolúveis, ou aos quais os acadêmicos - assim como os demais historiadores de sua época não têm como contornar com segurança até que transformações diversas no próprio exercício da historiografia surjam - entre elas, a criação de um ambiente disciplinar e a eleição do documento como fiador do discurso historiográfico. Ante essa situação, os acadêmicos têm de se haver com o caráter transitório de suas próprias palavras. O texto de José da Cunha Brochado que analisaremos a seguir é sintoma desta encruzilhada das reflexões acadêmicas, pois ele aponta simultaneamente para seu passado e seu futuro.

\section{O paradoxo dissecado}

Pode-se dividir o discurso aqui estudado em três partes. Na primeira, que serve de proêmio ao relato, o autor apresenta o problema que o persegue, assim como introduz algumas concepções preliminares acerca do que seja história e verdade. Em seguida, ele passa a explorar as causas pelas quais as histórias são pouco confiáveis, passando das mais gerais às particulares de cada autor. Esta seção ocupa a maior parte do texto. Por fim, após concluir pela virtual impossibilidade de uma história verdadeira, ele desenvolve a ideia que o orienta desde o início: a maior utilidade e facilidade da fábula para alcançar a verdade moral.

O autor enuncia logo de saída a questão que lhe preocupa, qual seja, "parece que na História não há verdade, ou que a verdade não é necessária na História" (CDMARHP 22/09/1730, p. 1). A formulação esconde dois problemas. Primeiro, por que a história não consegue alcançar a verdade? Segundo, por que a verdade, da forma como usualmente é o objetivo do historiador, torna-se, ao cabo, desnecessária? As duas seções restantes das quais se compõe o texto se ocupam, respectivamente, da tentativa de encontrar respostas a estas perguntas.

É importante passarmos em revista algumas definições adotadas por Brochado a respeito de seus objetos, de modo a compreender algumas de suas leituras e quais são seus interlocutores. A primeira dessas definições é a de história. Ele recorre ao polímata neerlandês Gerardus Joannis Vossius (15771649), autor de uma Ars historica publicada em 1623. Com base neste escritor, Brochado afirma que se a história é arte, então se define como "narração das coisas passadas com louvor ou vitupério", porém se a história é ciência, então se constitui enquanto "conhecimento dos particulares, dos quais a conservação da memória é útil a uma vida boa e piedosa" (CDMARHP 22/09/1730, p. 2). 0 que essas duas concepções demonstram a respeito do próprio entendimento de Brochado acerca da história?

A ars historica de Vossius pertence a uma última leva de escritos que levam este nome (outro representante é o Dell'Arte Istorica, de Agostino Mascardi, publicado em 1636). Este gênero alcançou sua maior popularidade no século XVI, quando desenvolveu uma aguda reflexão sobre a leitura da história e as condições para a confiabilidade do discurso histórico. No século XVII, contudo, estes escritos reforçam o enquadramento da história enquanto um gênero retórico-discursivo, centrando-se nos elementos de 
composição de uma boa história (GRAFTON 2007; MORAES JÚNIOR 2010; NICOLAZZI 2011). Vossius combina ambas as preocupações, definindo a história simultaneamente como uma narrativa literária e como uma atividade do conhecimento, porém o saber obtido por meio dela não pode alcançar o mesmo grau daquele derivado da scientia, a qual trata do que é necessário a partir de causas evidentes. ${ }^{4} \mathrm{Em}$ ambos os casos, portanto, a história encontra-se um grau aquém da certeza e da verdade.

Como se não bastasse, há a própria (in)determinação da verdade. A verdade é naturalmente elusiva aos intentos humanos de conhecê-la e o caráter temporal, distanciado e humano da história não contribui para a reversão deste quadro. Logo, as pretensões da história ao conhecimento podem ser condenadas já que "Não sabemos por nós o que somos, e queremos saber por ela o que temos sido" (CDMARHP 22/09/1730, p. 2). A história, narrativa moral e conhecimento particular; a verdade, inacessível aos olhos dos homens. Tem-se agora meios de compreender porque é tão difícil conjugar história e verdade.

Brochado começa a segunda parte de seu discurso com uma afirmação geral: os historiadores se fundam, diz ele, "sobre acepções incertas, e vulgares, memórias defeituosas, e conjecturas atrevidas, de sorte, que não há Historiador profano, que não necessite de apologista sobre a sua verdade" (CDMARHP 22/09/1730, p. 2-3). Além disso, "Quando um Historiador empreender escrever uma História, protesta logo sobre a sua verdade" (CDMARHP 22/09/1730, p. 3). Em suma, o historiador se vale de testemunhos incertos e mune-se de seu próprio 282 engenho para constituir e defender uma empreitada que, no fim, só se torna crível com base em sua própria autoridade. A credibilidade do discurso histórico está, dessa forma, em função direta da credibilidade do próprio historiador.

Para sua crítica, o acadêmico se vale de René Rapin (1621-1687), autor de um pequeno tratado intitulado Instructions pour l'histoire, editado em 1686. A referência a Rapin não é gratuita, pois além deste tratado, ele também compôs uma obra intitulada Reflexions sur la philosophie ancienne et moderne (1677). Com esta obra, o abade francês se juntou a um pequeno grupo de escritores - sobretudo franceses - que procurava reagir à filosofia cartesiana retomando a tradição do ceticismo acadêmico preservada nos trabalhos de Cícero (Academica, De natura deorum), Lucrécio e no Contra Academicos, de Agostinho. O uso que René Descartes fizera da dúvida como caminho do conhecimento suscitara um grande interesse pelo ceticismo; estes autores, entretanto, opunham-se à pretensão cartesiana de alcançar um conhecimento das causas e essências através do novo método de filosofar por ele proposta, assim como rejeitavam a redução da alma humana à faculdade intelectiva, o cogito (MAIA NETO 1997, p. 203). A posição acadêmica cristalizava-se na condenação da evidência empírica ao campo da opinião, de modo que todo conhecimento assim obtido é apenas provável ou verossímil. Não tardaremos a ver que esta é a opinião esposada por Brochado.

\footnotetext{
4 "Logo a História versa sobre as coisas contingentes, as quais são todas noções secundárias \& ações humanas, cuja preservação produz história; enquanto a ciência é das coisas necessárias; como Duns Scotus a definira, conhecimento certo de coisas necessárias, produzidas a partir de causas evidentes, com aplicação do entendimento às coisas cognoscíveis para força e benefício do raciocínio" (VOSSII 1653, p. 15).
} 
Torna-se importante distinguir entre a corrente cética acadêmica e a pirrônica, especialmente porque o debate historiográfico recente costuma confundir ceticismo e pirronismo. A tradição pirrônica foi retomada por volta da mesma época com a tradução dos tratados de Sextus Empiricus, filósofo do século II d.C., principal fonte para o conhecimento desta vertente filosófica antiga. Enquanto o ceticismo academico preservava a essência de uma verdade cognoscível porém impossível de ser penetrada pelo intelecto humano, de modo que existiriam tantas verdades quanto sujeitos, o pirronismo advogava a suspensão de qualquer juízo afirmativo a respeito da realidade (épokhe) levando a um estado de equilíbrio (ataraxia) (POPKIN 2000, p. 16). A dúvida pirrônica era muito mais poderosa que a acadêmica, porém esta se adequava mais àquele grupo de autores - como Rapin - que pretendiam preservar a validade de um conhecimento divino inacessível aos humanos. Esta epistemologia, de base jesuítica, encontra-se também em José da Cunha Brochado, procedendo a uma fusão entre as duas correntes céticas na qual a dianteira continua sendo a do academicismo.

O debate acerca do pirronismo histórico na Idade Moderna centra-se sobretudo no campo da história antiga. Na França, o debate se inicia com o Jugement sur les anciens et principaux historiens grecs et latins (1646) e, vinte anos depois, se intensifica com o opúsculo Du peu de certitude qu'il y a en histoire (1668), ambos escritos por François de La Mothe Le Vayer (1588-1672), continuando na Académie des Inscriptions et Belles-Lettres na primeira metade do século XVIII. Um eco desses debates é encontrado no texto de Brochado, quando ele procede à relativização de toda evidência historiográfica antiga: "Uns, e outros documentos, que hoje são antigos, e que também foram modernos, se escreveram, e compilaram por homens possuídos então dos mesmos afetos, e com a mesma suspeita" (CDMARHP 22/09/1730, p. 3). Ainda assim, se por um lado o autor afirma a impossibilidade da verdade na história, ele estabelece, por outro lado, que é apenas uma espécie de verdade - a factual, que seria captada pelos sentidos - que normalmente escapa ao discurso histórico. Da mesma forma, pode-se concluir, o saber sobre o passado particular é possível, desde que não se confunda com o conhecimento geral de uma vera scientia. Nesse sentido, no relato de José da Cunha Brochado, trata-se de mobilizar uma forma de ceticismo (o acadêmico) para combater a ameaça de outro (o pirrônico) e sua desconfiança de qualquer certeza. Brochado se vale do ceticismo para abrir brechas à verossimilhança do discurso histórico.

Essa discussão deixa sua marca sobre todo o texto, todavia o diplomata português elenca outros critérios de qualificação de um bom historiador. Estes critérios - estilo, clareza, disposição do relato, capacidade judicativa - não incidem, porém, sobre a relação entre história e verdade. A história é um discurso moral de grande valor, mas a discordância seja factual, seja entre os próprios historiadores, acaba por minar suas mais nobres pretensões.

Com isso, Brochado passa a individuar as histórias e os historiadores de acordo com sua dificuldade em produzir um discurso verdadeiro. A cronologia e a geografia, em primeiro lugar, consideradas os dois olhos da história, passam por seu escrutínio (CDMARHP 22/09/1730, p. 6). Em seguida, ele procede ao exame das tradições que contam a origem das monarquias. 
Assírios, persas, gregos e romanos têm em comum histórias fabulosas ou inverossímeis que relatam seu passado; sendo assim, até mesmo os fundamentos destas veneráveis instituições se perde nas brumas do passado (CDMARHP 22/09/1730, p. 6-9).

Os historiadores também não são perdoados por Brochado. Homero, Heródoto, Tucídides, Dion Cássio, Diodoro Sículo, Xenofonte, entre os gregos; Fábio Píctor, Tito Lívio, Júlio César, Patérculo, Quinto Cúrcio e Tácito, entre os latinos, assim como os modernos, todos eles pecam por dar vazão a suas opiniões pessoais, escrever louvores e estarem suscetíveis à inverossimilhança. A causa destes erros é, na verdade, sempre a mesma: a propensão dos historiadores à adulação e à parcialidade (CDMARHP 22/09/1730, p. 11). Este argumento, que remonta tanto a Cícero - uma vez que estes autores desrespeitam as leis da história $-^{5}$ quanto a Luciano, sofre uma reviravolta conforme o relato de José da Cunha Brochado ruma para sua conclusão.

Para o acadêmico, "Se pois parece, que não há verdade na História, não será difícil imaginar, que para o fim da História não é necessária a verdade" (CDMARHP 22/09/1730, p. 14). Como compreender uma afirmação dessas, ainda mais quando ela é enunciada numa agremiação dedicada ao conhecimento histórico? O caminho é entender como a fábula pode ser a tábua de salvação do discurso historiográfico.

Segundo o diplomata português, há duas espécies de verdade. Uma espécie é a que indica a concordância das palavras aos conceitos, engendrando um discurso sincero; a outra se revela quando há conformidade entre as palavras e as coisas, gerando um discurso verdadeiro ou verossímil. Como a verdade não nos é um dado imediato, ela só pode ser acessada conceitualmente através de um discurso adequado. Não há como apreender a realidade histórica a não ser indiretamente - logo, se a historiografia pretende ser verdadeira, só pode sê-lo de modo aproximativo. Esta verdade, estabelecida na mediação entre discurso e realidade, é a que instrui.

Brochado baseia sua argumentação na Cosmologia Sacra (1701), escrita pelo botânico inglês Nehemiah Grew (1641-1712). Ele provavelmente travou contato com esta obra durante sua estada inglesa e ela serve aos seus propósitos, pois, procurando estabelecer as bases do conhecimento da natureza, Grew sustenta que, se o mundo foi criado por vontade divina, ele não pode existir por moto próprio tampouco ser eterno ou infinito. Aos nossos olhos, porém, ele é indefinido, pois não se pode medir com precisão um efeito a partir de uma causa infinita, que é Deus (GREW 1701, p. 6). Há uma decalagem entre as formas de conhecimento que se combina com a do ceticismo acadêmico, utilizada por Brochado para salvaguardar a proeminência divina sobre o saber humano. Além disso, a obra de Grew permite ao acadêmico distinguir entre percepção, imaginação e intelecção - distinção com a qual Brochado encontra interlocutores portugueses para sua proposta.

\footnotetext{
5 "De fato, quem ignora que a primeira lei da história é não ousar dizer algo de falso? Em seguida, ousar dizer algo de verdadeiro? Não haver suspeita de favorecimento na escrita? Ou de ressentimento?" (CÍCERO II, 63, 206).
} 
Em 1717, Francisco Leitão Ferreira (1667-1735), colega de Brochado na Academia Real, publica a primeira parte de sua Nova Arte de Conceitos, resultado das conferências celebradas pela Academia dos Anônimos em Lisboa. A obra apresenta uma dupla categorização dos sentidos humanos. Eles podem ser exteriores - visão, audição, olfato, tato e paladar - ou interiores - sentido comum, fantasia, imaginação, estimação e memória. Estas duas classes de sentido concorrem para a criação de uma terceira categoria, a intelectiva ou conceitual. Dessa interação é criada uma ideia, de modo que "o conceituar seja um fingir, ou fazer imagens intrínsecas, \& insensíveis dos objetos sensíveis" (FERREIRA 1717, p. 51). Conceituar é fingir porque significa criar imagens não existentes na natureza - e o modo de comunicá-las é pelo discurso, que Ihes deve ser conforme. A natureza do discurso é, por assim dizer, ficcional, no sentido de algo criado que não possui existência independente da vontade humana. O entendimento é resultado de um ato intelectual capaz de desvelar a essência incorpórea da realidade. Essência esta que, na verdade, existe apenas como resultado do próprio intelecto, já que o homem é incapaz de penetrá-la por seus sentidos, algo que seria apanágio de Deus. E, como conclui Brochado, "Se a verdade pois é uma consequência da coisa com o entendimento [...] neste sentido toda a verdade instrutiva consiste menos na existência das coisas, que na sua verossimilhança", de modo que a "parábola pode entrar de igual passo com as Histórias, para o nosso ensino, e para a nossa cautela" (CDMARHP 22/09/1730, p. 15).

O que se segue, até o final do texto, é uma listagem das obras fabulosas, isto é, ficcionais, que servem à instrução. O interessante é resumir o movimento de Brochado neste discurso. De um lado, ele parte de um conceito de história como narração que visa à instrução moral e ao conhecimento das coisas incertas que Ihe possibilita realizar um desvio cético que retira da história a impossível verdade factual. Este desvio, entretanto, serve apenas para reforçar o aspecto moral da narrativa histórica - aliás, de qualquer narrativa. Segundo a concepção de discurso esposada por Brochado, este somente atinge eficácia se substitui sua pretensão de alcançar a realidade pela de encontrar uma verdade consoante com a adequação entre o dado sensível e a palavra. Toda verdade é uma verdade moral. E é apenas porque mobiliza um conceito tão tradicional de história que Brochado consegue igualá-la à ficção. Por outro lado, há um claro limite às pretensões da ficção, pois se esta tem de instruir assim como faz a história, ela também tem de estar sujeita à verossimilhança e à moralidade. A fábula ganha em relação à história por não depender da errônea percepção sensorial intrínseca ao ser humano, todavia a permissividade com relação ao conceito de história redunda em um claro interdito à ficcionalidade. Não por acaso, a forma de ficção privilegiada pelo diplomata é a parábola, que instrui por ser verossímil e é verossímil porque instrui.

\section{Conclusão}

Em 1974, Hayden White cunhou sentença que carregaria muito de sua fama pelas décadas e debates seguintes. Em "O texto histórico como artefato literário", o crítico e historiador norte-americano defendia que as narrativas 
históricas são "ficções verbais cujos conteúdos são tanto inventados quanto descobertos e cujas formas têm mais em comum com os seus equivalentes na literatura do que com seus correspondentes nas ciências" (WHITE 2001, p. 98). A frase chama atenção para a natureza essencialmente poética do discurso historiográfico, resultado, como ele afirmara na longa introdução a sua obra mais famosa, Metahistória, de uma "tentativa de mediação entre o que eu chamarei de campo histórico, o registro histórico não processado, outros relatos históricos e um público" (WHITE 2008, p. 21). Nas décadas seguintes, ambas as afirmações foram diversamente discutidas - e, muitas vezes, levadas a afirmações mais radicais acerca do relacionamento entre a construção do discurso histórico, um público e sua possível referencialidade -, todavia muito do debate acabou por manter a crença de que os condicionantes textuais são mais um empecilho a uma visão translúcida da verdade do que a condição intransponível para a confecção de um texto historiográfico crível (COSTA LIMA 2006, p. 37).

Não temos meios de discutir em detalhes a relação entre o linguistic turn e a escrita da história nas últimas quatro décadas, porém podemos destacar que o relato de José da Cunha Brochado somente alcança sua - sempre limitada - eficácia ao articular uma teoria do discurso histórico a uma teoria da linguagem chegando à problematização da ficção. Nesse sentido, ele articula as três pontas (história, fiç̧ão e epistemologia) que frequentemente são desassociadas ao se defender tal ou qual concepção de história sobre as demais. O discurso de Brochado também ajuda a revelar a intensidade dos debates em uma agremiação - a Academia Real

286 da História Portuguesa - e em uma historiografia no geral, a portuguesa, que por muito tempo se acreditou estar alheia à reflexão teórica. Essa reflexão acaba por tocar no ponto central que não se alterou desde que a historiografia fez seu primeiro surgimento: "não tendo um objeto próprio - como o têm as ciências particulares - , a história necessita partir da aporia da verdade. Sem essa aporia seu jogo não funciona" (COSTA LIMA 2006, p. 82). O discurso aqui analisado se encontra em um determinado momento desta aporia e nos permite reformular a pergunta inicial que conduziu ao paradoxo: por que é tão difícil acreditar na história?

\section{Referências bibliográficas}

BROCHADO, José da Cunha. Cartas. Lisboa: Sá da Costa, 1944.

Memórias de José da Cunha Brochado extraídas das suas obras inéditas. Coimbra: França Amado, 1909.

CÍCERO, De Oratore. In: SCATOLIN, Adriano. A invenção no Do Orador de Cícero: um estudo à luz de Ad Familiares I, 9, 23. São Paulo: FFLCH/USP, 2009, tese de doutoramento.

COLEÇÃo dos documentos, Estatutos e Memórias da Academia Real da História Portuguesa. Lisboa Ocidental: Oficina de Pascoal da Silva. Volumes referentes aos anos de 1721, 1722, 1723, 1729 e 1731.

COSTA LIMA, Luiz. História. Ficção. Literatura. São Paulo: Companhia das Letras, 2006. 
CUNHA, Norberto Ferreira da. A ilustração de José da Cunha Brochado. In: . Elites e académicos na cultura portuguesa setecentista.

Lisboa: Imprensa Nacional/Casa da Moeda, 2001, p. 49-79.

DELGADO, Maria Rosalino Pinto da Ponte. José da Cunha Brochado (16511733): o homem e a sua época. Lisboa: Universidade Lusíada, 2001.

FERREIRA, Francisco Leitão. Nova Arte de Conceitos. Lisboa Ocidental: Oficina de Antônio Pedrozo Galram, 1718. Parte I.

GRAFTON, Anthony. What was history? The Art of History in Early Modern Europe. Cambridge: Cambridge University Press, 2007.

GREW, Nehemiah. Cosmologia Sacra: or a discourse of the universe as it is the Creature and Kingdom of God. London: W. Rogers, S. Smith, B. Walford, 1701.

MAIA NETO, José R. Academic Skepticism in Early Modern Philosophy. Journal of the History of Ideas, vol. 58, $n^{\circ} 2$, apr. 1997, p. 199-220.

MORAES JÚNIOR, Hélvio Gomes. A crítica historiográfica nos Dez diálogos da História (Veneza, 1560): estudo e tradução comentada. Campinas: IEL/UNICAMP, 2010, tese de doutoramento.

MOTA, Isabel Ferreira da. A Academia Real da História: os intelectuais, o poder cultural e o poder monárquico. Coimbra: Minerva, 2004.

NICOLAZZI, Fernando. Como se deve ler a história? Jean Bodin e a ars histórica do século XVI. In: NICOLAZZI, Fernando; MOLLO, Helena Miranda; ARAUJO, Valdei Lopes de (orgs.). Aprender com a história?: o passado e o futuro de uma questão. Rio de Janeiro: Editora FGV, 2001, p. 207-234.

POPKIN, Richard. História do Ceticismo de Erasmo a Spinoza. Rio de Janeiro: Francisco Alves, 2000.

SANTA CATARINA, Frei Lucas de. Memórias da Ordem Militar de S. João de Malta. Lisboa Ocidental: Oficina de José Antônio da Silva, 1734.

SILVA LEAL, Manoel Pereira da. Memórias para a História Eclesiástica do Bispado da Guarda, parte primeira. Lisboa Ocidental: Oficina de José Antônio da Silva, 1729.

VOSSII, Gerardus Joannis. Ars histórica sive, de Historiae, \& Historices natura, Historiaque scribenda praeceptis, commentatio. Luodonus Batavorum: Ex Officina Joannis Maire, 1653.

WHITE, Hayden. O texto historiográfico como artefato literário. In:

Trópicos do discurso: ensaios sobre a crítica da cultura. São Paulo: EdUSP, 2001, p. 97-116.

- Meta-história: a imaginação histórica do século XIX. São Paulo: EdUSP, 2008. 